\title{
ASSESSMENT ON VORACITY AND PREDATION BY PREDATOR, Sycanus dichotomus STAL. (Hemiptera: Reduviidae) TO OIL PALM BAGWORM, Pteroma pendula
}

\section{SITI NURULHIDAYAH AHMAD*; MOHAMED MAZMIRA MOHD MASRI ${ }^{\star}$ and NORMAN KAMARUDIN*}

\begin{abstract}
Sycanus dichotomus Stal. (Hemiptera: Reduviidae) is a generalist predator with a wide prey spectrum that commonly preys on bagworms and nettle caterpillars in oil palm plantations in Malaysia. The voracity of fifth instar nymphs and adults (males and females) of S. dichotomus using Pteroma pendula Joannis (Lepidoptera: Psychidae) third instar larvae as prey was evaluated in the laboratory, as well as its relationship with the development stage and exposure time on the voracity and predation rate. The number of preys consumed by predators was recorded at every 3, 24 and $48 \mathrm{hr}$ intervals. The maximum voracity and predation rates were always greater in adults. The adult females displayed the highest prey consumption (1.0- 4.33 bagworms) followed by adult males (0.67-4.17 bagworms), and fifth instar nymphs (0.5-3.0 bagworms) at all time intervals. Although the fifth instar nymphs were able to kill the prey offered, the differences in predation potential indicated that the adult males and females were more vigorous and voracious in capturing and killing prey compared to the fifth instar nymphs. Results showed that the overall effect of the developmental stages of S. dichotomus on voracity and predation rate was highly significant $(F=10.420 ; d f=2 ; P<0.001)$. Similarly, the time intervals also exhibited a highly significant effect on the voracity and predation rate of $S$. dichotomus $(F=95.267 ; d f=2 ; P<0.001)$. However, the relationship between the predator developmental stages and exposure times was not significant $(F=2.444 ; d f=4 ; P=0.300)$. This finding indicates the potential of the adults' stage of $\mathrm{S}$. dichotomus to be released in the field, aiming for greater bagworm reduction in subsequent generation. In future research, it is necessary to assess the dynamic features of preypredator system in an actual oil palm field.
\end{abstract}

\section{Keywords: Sycanus dichotomus, predator, predation, voracity, Pteroma pendula, bagworm.}

Date received: 19 August 2019; Sent for revision: 20 August 2019; Accepted: 5 November 2019; Available online: 28 July 2020.

\section{INTRODUCTION}

Awareness in biological control has increased considerably in response to the various effects of pesticides on the environment. Biological control favours conservation, and the sustainable use of biological resources such as natural enemies of insects (Isaacs et al., 2009; Mazza et al., 2014;

Malaysian Palm Oil Board,

6 Persiaran Institusi, Bandar Baru Bangi,

43000 Kajang, Selangor, Malaysia.

E-mail: nurulhidayah@mpob.gov.my
Karamaouna et al., 2019). Symondson et al. (2002) summarised that the assemblages of generalist predators significantly reduced pest abundancy up to $79 \%$, decreasing a $65 \%$ loss to crops. On the other hand, study by Karamaouna et al. (2019) discovered the potential of ground cover with mixtures of selected plants as habitats for beneficial arthropods in an olive grove.

In Malaysia, oil palm is an important crop commodity which covers 5.81 million hectares of plantation area, in which the average of fresh fruit bunches (FFB) yield had increased to $17.16 \mathrm{t} \mathrm{ha}^{-1} \mathrm{yr}^{-1}$ 
in 2018 (Kushairi et al., 2019). Agriculture through large scale mono-cropping deliberately introduces alterations in the environment, exposing the crop to serious attacks of pests and diseases. When there is a breakdown in natural control, pest numbers might increase, and that can lead to a significant outbreak. Bagworms (Metisa plana, Pteroma pendula and Mahasena corbetti) and nettle caterpillars (Darna sp. and Setora nitens) are the most prevalent insect pests of the oil palm plantation in Malaysia (Norman et al., 2017). These bagworm species regularly damage oil palm leaves, leading to serious crop losses (Norman and Basri, 2007). Wood et al. (1973) reported that a $50 \%$ defoliation of the upper fronds by the bagworms had resulted in a yield loss of $43 \%$. Biological control methods are favoured to reduce bagworms and nettle caterpillars population, including the planting of beneficial plants for sustaining the parasitoids and predators (Basri et al., 1999; Wilcove and Koh 2010); pheromone trapping and spraying of bioinsecticide (Najib et al., 2017); and implementation of an integrated pest management system (Mazmira et al., 2015).

Predatory insects were proven to be effective biological control agents that provide an alternative to chemical dependence in agricultural systems (Jamian et al., 2017). The assassin bugs (Hemiptera: Reduviidae) are an important group of predators found in oil palm plantations (De Chenon et al., 1989). Among them, Sycanus dichotomus Stal. is the most common reduviid bug that feeds on nettle caterpillars such as Darna sp. and Setothosea asigna (De Chenon et al., 2017; Singh, 1992); and bagworms such as M. plana and P. pendula (Norman et al., 2017; Jamian et al., 2010). Previous studies had shown that reduviid predators were suitable biological control agents for nymphs and larvae of insect pests (Schaefer and Ahmad, 1987; Zulkefli et al., 2004; Siti Nurulhidayah and Norman, 2016; Jamian et al., 2017). Sycanus collaris had been successfully released as an important natural enemy to manage Helopeltis $\mathrm{sp}$. and leaf roller caterpillars in forest plantations in Sumatra, Indonesia (Budi et al., 2008). De Chenon et al. (1989) proved the successful use of S. dichotomus as a biocontrol agent for M. plana where an adult S. dichotomus would be able to consume an average of 430 young larvae of M. plana during its life-span. In Malaysia, a semi-field study conducted by Jamian and Nur Azura (2018) revealed that the maintenance of $S$. dichotomus population was eased by integration with beneficial plants. In an oil palm plantation, insect pests such as bagworms are commonly found feeding on an entire palm foliage. The possible usage of this predator as an effective biological control agent against oil palm insect pests such as bagworms was also identified in the study.

The balance ratio between the occurrence of predator and bagworm infestation is important for an integrated pest management (IPM) of the pest. The development of mass-rearing techniques is aimed at producing large numbers of healthy natural enemies of good quality. The right stage and timing are also crucial when releasing them in the field. Thus, this study was conducted to evaluate the voracity and predation rate of fifth instar nymphs and adults (males and females) of $S$. dichotomus using third instar P. pendula larvae as preys, as well as to evaluate its relationship with the development stage and exposure time in relation to predation efficiency. The results may be useful for understanding the predator's population dynamics in the field in relation to the availability of natural prey species.

\section{MATERIALS AND METHODS}

\section{Environmental Conditions}

The study was conducted at the Entomology Laboratory, Malaysian Palm Oil Board (MPOB), Bandar Baru Bangi, Selangor, Malaysia $\left(2^{\circ} 58^{\prime} 07.5^{\prime \prime} \mathrm{N}\right.$ and $\left.101^{\circ} 44^{\prime} 31.8^{\prime \prime} \mathrm{E}\right)$. All insect rearing and experiments were carried out in an environmentally controlled room at day temperature of $27 \pm 1^{\circ} \mathrm{C}$, night temperature of $24 \pm 1^{\circ} \mathrm{C}$, a photoperiod of $12: 12$ (L:D) hour and 50\%-70\% relative humidity, monitored with a hygrothermograph (Dickson brand).

\section{Insects' Rearing}

A culture of $S$. dichotomus was established in the laboratory using specimens originating from a field collection in Tapah and Teluk Intan, Perak, Malaysia. The adults were paired and caged in a transparent cylinder cage $(12.5 \mathrm{~cm}$ diameter $\times 23.5$ $\mathrm{cm}$ height) with a ventilated lid. Small ferns and oil palm leaflets were provided in the rearing cage to mimic their concealed microhabitat and for egg laying. All development stages of the predator were fed on alternative prey larvae such as mealworm, Tenebrio molitor and rice moth, Corcyra cephalonica. However, twice a month they were provided with bagworm larvae. Mixed prey larvae were provided to supply a more broadened group of nutrients to the predator. Diluted honey solution was also provided daily as the food source. The predators were reared in small batches in the rearing cages. The rearing of the $S$. dichotomus was carried out based on methods utilised by Siti Nurulhidayah and Norman (2016). Individuals (fifth instar nymphs, adult males and adult females) produced in this rearing system were used for the experiments (Figure 1). The rationalisation of the selection of these stages is due to the aim of having them released in the oil palm plantation in order to warrant optimum predator size for maximum predation rate. During the rearing process, it was observed that the final instar nymphs (fifth instar, with a mean body length 

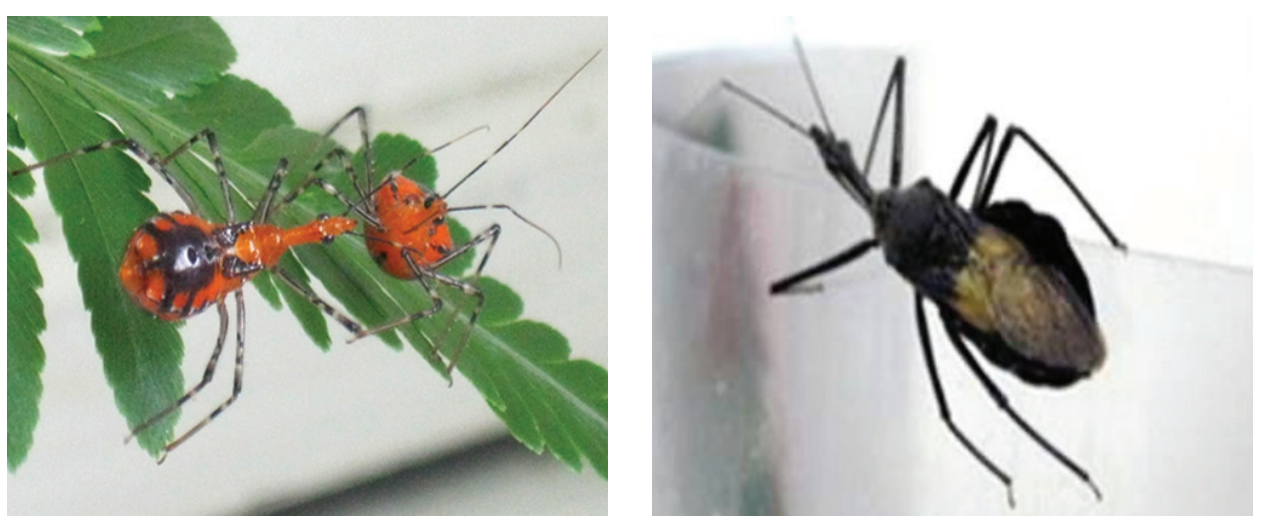

Figure 1. The fifth instar nymphs (left) and adult stage (right) of S. dichotomus.

of $22.3 \pm 0.517 \mathrm{~mm}$ ) were the most voracious among the other nymphal instars, particularly when fed with bagworms (Siti Nurulhidayah, unpublished).

\section{Voracity and Prey Consumption}

Prior to the experiments, fifth instar nymphs, adult males and adult females were held in separate cages and ad libitum-fed with the larvae of bagworm Pteroma pendula. Nymphs were maintained under these conditions for $24 \mathrm{hr}$ after moulting to the fifth instar - similarly with the adults after their emergence, without any prey prior to the experiment. Only moistened honey cotton was offered in a Petri dish that was replenished daily. Adult males and females can be distinguished by their body and abdominal sizes with the males being smaller. The purpose of using newly moulted predator was to standardise the age of the predator for fair observations. Any predator's nymph that moulted during the experiments might affect the feeding rates (Fantinou et al., 2009).

Pteroma pendula larvae were collected from the infested oil palm plantation in Teluk Intan, Perak and maintained in the laboratory at day temperature of $27 \pm 1^{\circ} \mathrm{C}$, night temperature of $24 \pm 1^{\circ} \mathrm{C}$, a photoperiod of $12: 12$ (L:D) hour and $50 \%$ $70 \%$ relative humidity. A total of 10 third instar larvae of $P$. pendula were offered in order to evaluate the predation rate. The third instar P. pendula larvae were selected to ensure an intermediate size for maximum prey consumption by the predator. Ten $P$. pendula larvae were placed gently on oil palm leaf cutting (20 cm long) as their food and left in an experimental cage $(12.5 \mathrm{~cm}$ diameter x 23.5 $\mathrm{cm}$ height). The bagworms were left undisturbed for $1 \mathrm{hr}$ to settle. At the beginning of the test, the individual $24 \mathrm{hr}$-starved fifth instar nymph of $S$. dichotomus was introduced from the rearing cage to the experimental cage containing $P$. pendula. The moistened honey cotton was also offered in a Petri dish. The similar procedure was repeated to adult males and females. Ten replicates for each treatment were performed. Control treatment was performed with the same prey numbers in the absence of the predators. At 3, 24 and $48 \mathrm{hr}$ after the start of the experiment, the interaction and predation activities were determined by the numbers of live and preyed bagworms in each experimental cage. These time intervals were chosen to measure the voracity of S. dichotomus. Dead preys were replaced daily to keep the prey density constant throughout the experiment.

\section{Statistical Analyses}

Determination of the voracity and prey consumption rate among fifth instar nymphs, adult males and adult females of $S$. dichotomus with a consistent number of preys given within exposure times were analysed using one-way analysis of variance (ANOVA), where the $\mathrm{F}$ test indicated a significant difference among different treatments means. Least Significant Difference (LSD) test at $\mathrm{P}<0.05$ was used to determine difference in the mean. Interaction between the development stages of predators and exposure times was analysed using two-way ANOVA. Comparisons among means were conducted using all pairwise multiple comparison procedures (Holm-Sidak method) of significance test at 5\% levels (SigmaPlot version 12.5).

\section{RESULTS AND DISCUSSION}

The predation activity of $S$. dichotomus towards $P$. pendula was observed in individual experimental cages in the laboratory. The study of the predation rates, as well as interaction between different developmental stages of predator and exposure time intervals allows the evaluation of the voracity and predation assessment of $S$. dichotomus.

Within the first $3 \mathrm{hr}$ of the observation, there was no significant difference on the voracity or prey consumption among the fifth instar nymphs, adult males and adult females (Figure 2). Among the developmental stages/gender, it was observed that there was a significant difference on the mean 
number of preys consumed between fifth instar nymphs and females after 24 hr of exposure (Figure 2). After $48 \mathrm{hr}$ of exposure, it was found that both adult genders recorded significant differences with fifth instar nymphs in prey consumption. No significant difference was observed between males and females in their prey consumption or voracity during first $3 \mathrm{hr}$ of exposure, as presented in Table 1. It is noteworthy that voracity of females and males did not differ. The number of unconsumed preys was generally kept at low levels and did not differ significantly among developmental stages/ gender and exposure time intervals. For all exposure time intervals, it was recorded that the fifth instar nymphs consumed the least number of bagworms. The adult males consumed most, followed by the adult females. It was also recorded that predation efficiency increased as $S$. dichotomus developed from fifth instar to the adult. The relatively highest number of preys was consumed by adult females; $1.0 \pm 0.258,2.33 \pm 0.211$ and $4.33 \pm 0.211$ for 3,24 and $48 \mathrm{hr}$, respectively (Table 1 ).

The experiment demonstrated that the voracity and prey consumption of the adult females were higher compared to the males and fifth instar nymphs. In general, the maximum predation rate values were always greater for both adult genders of $S$. dichotomus. Consequently, differences in predation rate, attack rate and handling time also indicate that the adults were more vigorous and voracious in capturing and killing prey compared to the fifth instar nymphs. A similar finding was recorded by Milonas et al. (2011). Furthermore, higher attack rate and shorter handling time in adults, particularly the females, indicate that the adult females are the most voracious stage. This condition verifies that the fifth instar nymphs had a lower predation rate based on the number of preys consumed. This might be due to their lower attack rates and longer prey handling time, as suggested by Milonas et al. (2011).

Results of the two-way ANOVA showed that the overall effect of developmental stages of $S$. dichotomus on voracity and predation rate was highly significant $(\mathrm{F}=10.420 ; \mathrm{df}=2 ; \mathrm{P}<0.001)$. A similar finding was reported by Santos et al. (2016). They revealed that the success of a predator depends on behavioural characteristics, which can be affected by many factors, including the

TABLE 1. VORACITY (mean number of preys consumed \pm standards error) OF P. pendula LARVAE CONSUMED BY S. dichotomus FOR DIFFERENT EXPOSURE TIME INTERVALS

\begin{tabular}{ccccc}
\hline \multirow{2}{*}{$\begin{array}{c}\text { Exposure time } \\
(\mathbf{h r})\end{array}$} & Fifth instar nymphs & Adult males & Adult females & \multirow{2}{*}{ ANOVA } \\
\cline { 2 - 4 } & $0.5 \pm 0.224$ & $0.67 \pm 0.211$ & $1.0 \pm 0.258$ & n.s. \\
24 & $1.0 \pm 0.258$ & $1.5 \pm 0.428$ & $2.33 \pm 0.211$ & $*$ \\
48 & $3.0 \pm 0.365$ & $4.17 \pm 0.307$ & $4.33 \pm 0.211$ & $*$ \\
\hline
\end{tabular}

Note: ANOVA - analysis of variance. n.s. - not significant. *Significant at $\mathrm{P}<0.05$ within the same row.

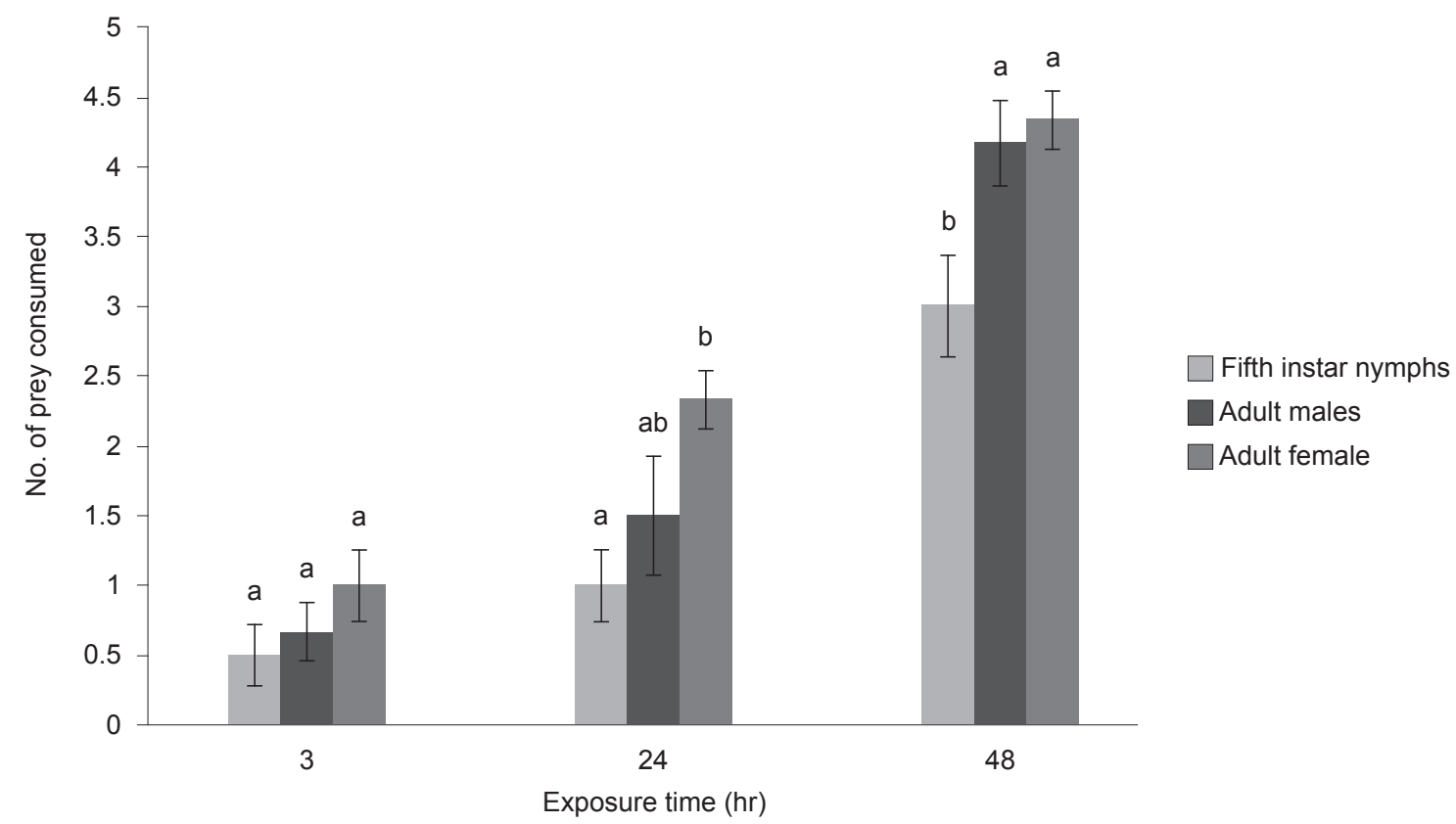

Figure 2. Mean ( \pm standard error) prey consumption by fifth instar nymphs, adult males and adult females of S. dichotomus showed by different exposure times. Means within each exposure time followed by different letters indicate significant differences between them (Least Significant Difference test; $P<0.05)$. 
TABLE 2. TWO-WAY ANALYSIS OF VARIANCE (ANOVA) ON THE PROPORTION OF PREY CONSUMED BY DIFFERENT DEVELOPMENT STAGES OF S. dichotomus IN RELATION TO EXPOSURE TIMES

\begin{tabular}{lcrrrr}
\hline Parameter & DF & SS & MS & F & P \\
\hline Development stage & 2 & 10.111 & 5.056 & 10.420 & $<0.001$ \\
Exposure time & 2 & 92.444 & 46.222 & 95.267 & $<0.001$ \\
Development stage x exposure time & 4 & 2.444 & 0.611 & 1.260 & 0.300 \\
\hline
\end{tabular}

Note: DF - degree of freedom.

SS - sum of squares.

MS - mean squares.

F - F-value.

P- P-value.

predator's developmental stage. Similarly, the time intervals also exhibited a highly significant effect on the voracity and predation rate of $S$. dichotomus $(\mathrm{F}=$ 95.267; $\mathrm{df}=2 ; \mathrm{P}<0.001)$. However, the interaction of predator developmental stages and exposure times was not significant $(\mathrm{F}=2.444 ; \mathrm{df}=4 ; \mathrm{P}=0.300)$ as shown in Table 2.

The P. pendula third instar larvae offered were approximately the same in terms of developmental stage, size and mobility. These factors may account for their acceptance by $S$. dichotomus, which could be explained through the functional response model that incorporated both predator and prey size (Aljetlawi et al., 2004). Other factors, such as the long-term mass-rearing of the predator and the nutritional value of the prey may have influenced the results. Changes in predation behaviour associated with the age or stage of the predator have been well documented among invertebrates, including insects (McKemey et al., 2003; Troost et al., 2008). It has also been reported that the mean prey size increases with the body size of the predator (McArdle and Lawton, 1979; Cisneros and Rosenheim, 1997).

Based from observations during the experiment, S. dichotomus had attacked the bagworm larvae by penetrating its rostrum inside the anterior part of the bagworm (Figure 3). After the penetration, the predator remained motionless for a few minutes until the larvae stopped moving. The predator was inactive during feeding except when disturbed. This would last for several minutes to over an hour, as stated by Green (1973). The bagworms were entirely consumed by the predator and only their skin remained. This was observed after the dissection of the bagworm bag (Figure 4). This condition can be related with observations recorded by Ables (1978), that reduviid predators generally prefer lepidopteran caterpillars due to their soft cuticle and slow movement. In few cases, it was also observed that $S$. dichotomus would occasionally abandon a prey item that had already been killed during the experiment. This feeding behaviour, in which killed preys are either abandoned or left partially unconsumed has also been recorded in other predator studies (Lang and Gsödl, 2003; Fantinou et al., 2009).

While conducting the predation test, it was revealed that during the prey search and attack, the voracity differs between the sexes. As previously hypothesised by Lucas et al. (1997) and Evans and Gunther (2005), adult females are usually more voracious than males owing to their larger size and high requirements of nutrients for egg production and oviposition. However, under such conditions and due to the smaller size of the males, it was convenient for them to catch smaller preys although larger ones offer higher energetic gain, since capture success generally decreases with increasing prey size (Hassell et al., 1976; Roger et al., 2000; Soares et al., 2004). In addition, previous studies also show that food quality might affect the survival of several predators (Isikber and Copland, 2002; Kalushkov and Hodek, 2004), as well as the reproductive performance of the adults.

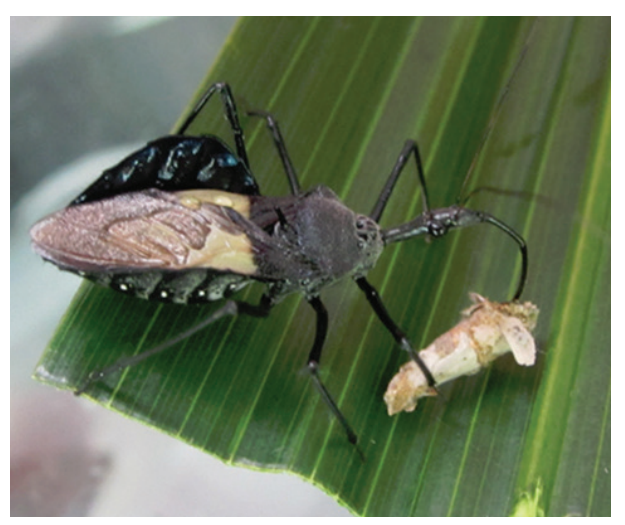

Figure 3. The predator attacked the bagworm larvae by penetrating its rostrum inside the anterior part of the bagworm.

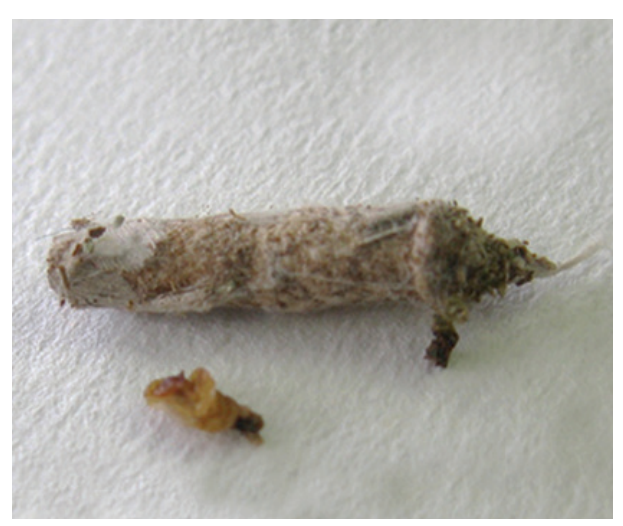

Figure 4. Bagworm that was entirely consumed by the predator was left with only its skin remained. 


\section{CONCLUSION}

Equal proportions of $P$. pendula instar larvae offered towards $S$. dichotomus showed a differential predation pattern with the greatest predation occurrence by the adults, particularly females. Overall, the results indicated that the adults $S$. dichotomus were more vigorous and voracious in consuming $P$. pendula instar larvae compared to the fifth instar nymph under controlled conditions. Although the relationship between the predator developmental stages and exposure times was not significant, this study revealed that predatory behaviour was influenced by the body mass and gender. The body mass and sex ratios of the adults might vary depending on the food source given during the rearing process (Siti Nurulhidayah and Norman, 2016). This finding may compensate the biological control of bagworms in oil palm crops. It also suggests that with better strategy according to its voracity capacity, increased level of control can be achieved. Regarding the higher voracity of the adults on P. pendula, it somehow suggests that this predator can be a useful biological control agent. An estimated maximum predation rate can be used to define optimal number of individual predators released in order to suppress prey in the field. The results of the present study indicate that the predator's developmental stage and foraging strategy might be components of a dynamic prey-predator system that needs more research and understanding. Further experiments on the influence of the environmental factors on the predator population in the field are required in order to clarify the voracity level of S. dichotomus on natural preys, as well as their availability on the predator's food preference. Therefore, prey preference of $S$. dichotomus towards $P$. pendula or other bagworm species in the field needs further investigation before the control efficacy of this predator against these prevalent oil palm insect pests can be fully determined. Furthermore, factors such as abiotic factors, prey availability, prey type and plant host may act simultaneously under the actual field conditions. Thus, the promising results of this study warrant further investigation on the possibility of using $S$. dichotomus or other species of the same family for practical control of oil palm insect pests. Mass production of these predators may be feasible at a relatively low cost, suggesting the possibility of releasing them periodically for insect pest control especially in oil palm plantations.

\section{ACKNOWLEDGEMENT}

The authors would like to thank the Director-General of MPOB for permission to publish this article. Special thanks also go to the staff of Entomology and Ecological Research Group, MPOB: Othman Arshad, Noor Hasan Mohd Yob, Tunku Akhiruddin Tunku Aris, Hajijah Shamsuddin, Zuriahti Khamis and the late Mat Tahir Bong Ruziz for their assistance in the laboratory and field works.

\section{REFERENCES}

Ables, J R (1978). Feeding behaviour of an assassin bug, Zelus renardii. Ann. Entomol. Soc. Am., 71(4): 476-478.

Aljetlawi, A A; Sparrevik, E and Leonardsson, K (2004). Prey-predator size dependent functional response: Derivation and rescaling to the real world. J. Animal Ecology, 73: 239-252.

Basri, M W; Simon, S; Ravigadevi, S and Othman, A (1999). Beneficial plants for the natural enemies of the bagworm in oil palm plantations. Proc. of the 1999 PORIM International Palm Oil Congress Emerging Technologies and Opportunities in the Next Millennium (Ariffin, D; Chan, K W and Sharifah, S R S A eds.). PORIM, Bangi. p. 441-455.

Budi, T; Gafur, A; Nasution, A and Golani, G D (2008). Application of Sycanus collaris as biocontrol agent for insect pests in plantation forestry (abstract). International Congress of Entomology (ICE 2008). Durban, South Africa. 6-12 July 2008. 1 pp.

Cisneros, J J and Rosenheim, J A (1997). Ontogenetic change of prey preference in the generalist predator Zelus renardii and its influence on predator-Predator interactions. Ecological Entomology, 22: 399-407.

De Chenon, R D; Sipayung, A and Sudharto, P $S$ (1989). The importance of natural enemies on leaf-eating caterpillars in oil palm plantations in Sumatra, Indonesia - Uses and possibilities. Proc. of the PORIM International Palm Oil Development Conference. PORIM, Bangi. p. 245-262.

Evans, E W and Gunther, D I (2005). The link between food and reproduction in aphidophagous predators: A case study with Harmonia axyridis (Coleoptera: Coccinellidae). European J. Entomology, 102: 423-430.

Fantinou, A A; Ch Perdikis, D; Labropoulos, P D and Maselou, D A (2009). Preference and consumption of Macrolophus pygmaeus preying on mixed instar assemblages of Myzus persicae. Biological Control, 51: 76-80.

Green, G L (1973). Biological studies of a predator Sycanus indigator: Life history and feeding habits. The Florida Entomologist, 56(3): 255-257. 
Hassell, M P; Lawton, J H and Beddington, J R (1976). The components of arthropod predation: The prey death-rate. J. Animal Ecology, 45: 135-164.

Isaacs, R; Tuell, J; Fiedler, A; Gardiner, $\mathrm{M}$ and Landis, D (2009). Maximizing arthropod-mediated ecosystem services in agricultural landscapes: The role of native plants. Frontiers in Ecology and the Environment, 7: 196-203.

Isikber, A A and Copland, M J W (2002). Effects of various aphid foods on Cycloneda sanguinea. Entomologia Experimentalis et Applicata, 102: 93-97.

Jamian, S; Muhammad, R; Norman, K and Idris, A B (2010). Feeding behaviour and predatory efficiency of assassin bug, Sycanus dichotomus Stal. on oil palm bagworm, Metisa plana Walker. Malaysian Applied Biology, 39(2): 51-55.

Jamian, S; Ahmad, N; Ghazali, A; Zakaria, A and Azhar, B (2017). Impacts of 2 species of predatory reduviidae on bagworms in oil palm plantations. Insect Science, 24(2): 285-294.

Jamian, S and Nur Azura, A (2018). The performance of predatory insect, Sycanus dichotomus Stal. (Hemiptera: Reduviidae) on combination of plant host and prey. Serangga, 23(2): 56-64.

Kalushkov, P and Hodek, I (2004). The effects of thirteen species of aphids on some life history parameters of the ladybird Coccinella septempunctata. BioControl, 49: 21-32.

Karamaouna, F; Kati, V; Volakakis, N; Varikou, K; Garantonakis, N; Economou, L; Birouraki, A; Markellou, E; Liberopoulou, S and Edwards, M (2019). Ground cover management with mixtures of flowering plants to enhance insect pollinators and natural enemies of pests in olive groves. Agriculture, Ecosystems and Environment, 274: 76-89.

Kushairi, A; Meilina Ong-Abdullah; Balu Nambiappan; Elina Hishamuddin; Mohd Noor Izuddin Zanal Bidin; Razmah, G; Vijaya Subramaniam; Shamala Sundram and Ghulam Kadir Ahmad Parveez (2019). Oil palm economic performance in Malaysia and R\&D progress in 2018. J. Oil Palm Res. Vol. 31(2): 165-194.

Lang, A and Gsödl, S (2003). Superfluous killing of aphids: A potentially beneficial behaviour of the predator Poecilus cupreus (L.) (Coleoptera: Carabidae). J. Plant Diseases Protection, 100: 583-590.

Lucas, É; Coderre, D and Vincent, C (1997). Voracity and feeding preference of two aphidophagous coccinellids on Aphis citricola and Tetranychusurticae. Entomologia Experimentalis et Applicata, 85: 151-159.

Mazmira, M M M; Najib, M A; Norhazwani, K; Norman, K and Siti Ramlah, A A (2015). Implementing an Integrated Pest Management (IPM) program for bagworm control in oil palm smallholdings in Johor. Proc. of the PIPOC 2015 International Palm Oil Congress - Oil Palm: Powering the World, Sustaining the Future. MPOB, Bangi. p. 1520. www.researchgate.net/publication/368708846_ implementing_an_integrated_pest.

Mazza, G; Francardi, V; Simoni, S; Benvenuti, C; Cervo, R; Faleiro, J R; Llácer, E; Longo, S; Nannelli, R; Tarasco, E and Roversi, P F (2014). An overview on the natural enemies of Rhynchophorus palm weevils, with focus on $R$. ferrugineus. Biological Control, 77: 83-92.

McArdle, B H and Lawton, J H (1979). Effects of prey-size and predator-instar on the predation of Daphnia by Notonecta. Ecological Entomology, 4: 267275.

McKemey, A R; Symondson, W O C and Glen, D $M$ (2003). Predation and prey size choice by the carabid beetle Pterostichus melanarius (Coleoptera: Carabidae): The dangers of extrapolating from laboratory to field. Bulletin of Entomological Research, 93: 227-234.

Milonas, P G; Kontodimas, D C and Martinou, A F (2011). Predator's functional response: Influence of prey species and size. Biological Control, 59: 141146.

Najib, M A; Norman, K; Siti Nurulhidayah, A; Othman, A; Mazmira, M M M; Ramle, M and Kushairi, A (2017). Efficacy of pheromone trapping and aerial spraying of Bacillus thuringiensis (Bt) for controlling bagworm, Metisa plana Walker (Lepidoptera: Psychidae) in Yong Peng, Johor, Malaysia. J. Oil Palm Res. Vol. 29(1): 55-65.

Norman, K; Basri, M W and Zulkefli, M (2017). Handbook of Common Parasitoids and Predators Associated with Bagworms and Nettle Caterpillars in Oil Palm Plantations. MPOB, Bangi. 30 pp.

Norman, K and Basri, M W (2007). Status of common insect pest in relation to technology adoption. The Planter, 83: 371-385.

Roger, C; Coderre, D and Boivin, G (2000). Differential prey utilization by the generalist predator Coleomegilla maculata Lengi according to prey size and species. Entomologia Experimentalis et Applicata, 94: 3-13. 
Santos, B D B; Ramalho, F S; Malaquias, J B; Lira, A C S; Pachú, J K; Fernandes, F S and Zanuncio, J C (2016). How predation by Podisus nigrispinus is influenced by developmental stage and density of its prey Alabama argillacea. Entomologia Experimentalis et Applicata, 158: 142-151.

Schaefer, C W and Ahmad, I (1987). Parasites and predators of Pyrrhocoroidea (Hemiptera) and possible control of cotton stainers by Phonoctonus spp. (Hemiptera: Reduviidae). Entomophaga, 32: 269275.

SigmaPlot for Windows Version 12.5. Systat Software, Inc. Germany (2008).

Singh, G (1992). Management of oil palm pests and diseases in Malaysia in 2000. Pest Management and Environment in 2000 (Aziz, A; Kadar, S A and Barlow, H S eds.). p. 195-212.

Siti Nurulhidayah, A and Norman, K (2016). Growth and longevity of the insect predator, Sycanus dichotomus Stal. (Hemiptera: Reduviidae) fed on live insect larvae. J. Oil Palm Res. Vol. 28(4): 471-478.

Soares, A O; Coderre, D and Schanderl, H (2004). Dietary self-selection behaviour by the adults of the aphidophagous ladybeetle Harmonia axyridis (Coleoptera: Coccinellidae). J. Animal Ecology, 73: 478-486.

Symondson, W O C; Sunderland, K D and Greenstone, M H (2002). Can generalist predators be effective biocontrol agents? Annu. Rev. Entomol., 47: 561-594.

Troost, T A; Kooi, B W and Dieckmann, U (2008). Joint evolution of predator body size and prey-size preference. Evolutionary Ecology, 22: 771-799.

Wilcove, D S and Koh, L P (2010). Addressing the threats to biodiversity from oil-palm agriculture. Biodivers. Conserv., 19: 999-1007.

Wood, B J; Corley, R H V and Goh, K H (1973). Studies on the effect of pest damage on oil palm yield. Advances in Oil Palm Cultivation (Wastie, R L and Earp, D A eds.). Incorporated Society of Planters, Kuala Lumpur. p. 360-369.

Zulkefli, M; Norman, K and Basri, M W (2004). Life cycle of Sycanus dichotomus (Hemiptera: Pentatomidae) - A common predator of bagworm in oil palm. J. Oil Palm Res. Vol. 16(2): 50-56. 